\title{
HEY1 wt Allele
}

National Cancer Institute

\section{Source}

National Cancer Institute. HEY1 wt Allele. NCI Thesaurus. Code C101108.

Human HEY1 wild-type allele is located in the vicinity of $8 \mathrm{q} 21$ and is approximately $4 \mathrm{~kb}$ in length. This allele, which encodes hairy/enhancer-of-split related with YRPW motif protein 1 , plays a role in protein dimerization and the negative regulation of transcription. 